\title{
Smoking around the campfire: A San encounter with the colonial
}

\author{
Michael Wessels
}

\begin{abstract}
In 1873 Joseph Orpen, resident of Nomansland, engaged a San1 man Qing to guide a combined force of levies and mounted police through the Maloti mountains in present-day Lesotho where they hoped to intercept a group of reluctant Hlubi rebels under chief Langalibalele. Orpen was not only a colonial official but also a keen scholar. In response to his questions Qing commented on some of the rock paintings they saw on their short journey and recounted folklore. A year later Qing's narratives and his comments on rock art were published along with Orpen's account of the journey and 'remarks' by the celebrated linguist and collector of |Xam narrative, Wilhelm Bleek in an article in the Cape Monthly Magazine (CMM). Orpen's piece has enjoyed a seminal position in San studies ever since, especially in the field of rock art. The encounter between Qing and Orpen occurred in a context of colonial violence. Not only was the campaign that was being pursued against Langalibalele and his men unnecessary but the San had been subject to genocidal attacks by both regular and irregular colonial forces for a considerable period of time, and the studies of San rock art and narrative at the time were largely carried out in an intellectual climate that saw the extinction of the San as inevitable. This article will locate the CMM article more firmly in its colonial context by combining a close reading of elements of the CMM article itself with a consideration of a wider body of writing that relates to Orpen's piece.
\end{abstract}

In 1873 Joseph Orpen was appointed the British resident of Nomansland, a region that today straddles the north-western parts of the eastern Cape and south-eastern KwaZuluNatal. The area still lay outside British control, and Orpen's role, in his own words, was 'to initiate the policy of annexing to the Cape the territories between that Colony and Natal' (Orpen 1964 [1908]: 1). The annexation itself was accomplished in 1874. Before then, though, towards the end of 1873, Orpen was called upon by the Natal government to contribute a force of African levies to help apprehend the Hlubi chieftain Langalibalele and his men who had taken refuge in the Maloti mountains of present-day Lesotho after refusing to surrender guns to the Natal authorities. Orpen's force linked up with a contingent of mounted police under Inspector James Murray Grant, a career officer in the Frontier and Armed Mounted Police who, in his own mind at least, had overall command (Mitchell \& Challis 2008: 400-1). ${ }^{2}$ Orpen (1874:1) managed to 'secure' the 'services' of a man named Qing to guide the expedition through the Maloti. ${ }^{3}$ Qing was a man of San origin and identity who worked as a hunter for Nqasha, son of Moorosi, chief of the BaPhuthi, 'an ethnically 
heterogeneous group with a substantial Bushman component' (King 2014: 16). Much of the area through which Qing led the colonial force had long been chiefly the preserve of bands of San hunter-gatherers (Mitchell 2009: 18), although by the end of the decade it would be settled by Sotho agro-pastoralists and incorporated into the Basotho kingdom (Mitchell \& Challis 2008: 400). Orpen took the opportunity of travelling in the company of a San man through an area rich in rock art to pursue his interest in San painting and mythology, an interest inspired in part at least by his acquaintance with rock art copyist George Stow (Orpen 1964: 2), who in turn would later draw on Orpen's unpublished notes for his The Native Races of South Africa (1905), described by Alan Barnard (2007:34) as 'the first true Bushman ethnography' (2007:34), ${ }_{4}$ and probably also by his previous encounters with San people, some of which are described in his account of his time as a magistrate and parliamentarian in the Orange Free State (Orpen 1964).

Orpen made rock art copies in the great rock shelters of Melikane and Sehonghong. Qing interpreted some of the rock art panels that covered the walls of the shelters for Orpen and also recounted a series of narratives on their journey together through the mountains. These were translated with the help of an interpreter (or interpreters) from among the native auxiliaries, recorded by Orpen and published a year later in the Cape Monthly Magazine $(C M M)$ in an essay titled 'Glimpse into Bushman Mythology', with comments by the celebrated linguist and collector of |Xam narratives, Wilhelm Bleek. 5 Orpen's essay has been of seminal importance in rock art studies ever since. In the view of influential rock art scholar David LewisWilliams it 'as the single most important contribution to our understanding of the Drakensberg art' (2003: 17). ${ }^{6}$ Mitchell \& Challis (2008: 399) describeit 'as the only account of Bushman rock paintingsgiven by a Bushman informant with first-hand familiarity with the art'.7

With some exceptions, the stories, as opposed to Qing's comments on rock art, have not yet received the detailed analysis they deserve (McGranaghan, Challis \& Lewis-Williams 2013: 140). ${ }^{8}$

Orpen's interest in San folklore and painting must have puzzled Qing. White men in his experience had been intent on killing San people rather than listening to them: 'he had never seen a white man but in fighting' (Orpen 1874: 2). While Qing might have struggled to reconcile the European interest in San culture with European efforts to exterminate and enslave the San, a postcolonial vantage point does reveal a connection between thetwo. Wilhelm Bleek regarded the extinction of the San as inevitable (Thornton 1983; Bank 1999; Moran 2009). This gave the task of recording Sanculture and language its urgency. It is not surprising that Orpen himself shares this view given his first-hand experience of the irresistible pressures being brought to bear on groups identifiable as San or part San. He positions Qing in his text as an anomaly, a rare survivor from the past: 'one Bushman, named Qing, a coupleyears ago escaped from the extermination of their remnant of a tribe in the Malutis' (Orpen 1874: 2). Even the group of San to which he belonged were atypical survivors: 'They have been gradually exterminated by wars with all other tribes (even with Bushmen tribes) and Europeans, and their remnant was long living secluded in the Maluti, hunting game and occasionally making raids' (Orpen 1874: 6). Qing is thus 
a remnant of a 'remnant'. Orpen's views of the disappearance of the San would have been reinforced by the fact that the area through which he and Qing travelled was unusually empty in 1873 (Mitchell \& Challis 2008: 404), a time sandwiched between the planned and systematic occupation by Basotho clans of the area in the 1880 s and attacks on the San by Basotho forces from the west and from the east by colonial forces and African groups like the Hlubi, several of whom had been settled in the Drakensberg foothills of Natal to provide a buffer between the settlers and the San (Wright \& Mazel 2007: 116-7; Mitchell 2009: 18).

This article will examine afresh the nature of the colonial text that resulted from the encounter between Qing and Orpen, combining the literary technique of close reading with a consideration of the insights gleaned from the rich assemblage of secondary material that relates to the $C M M$ article and the period by historians, archaeologists, and other scholars.

\section{The Text}

The writing in which Orpen himself is the focaliser, occupies about a third of the overall text, half as much space as Qing's narratives, although this is misleading for Qing's narratives are extraordinarily compressed. His remarks on the paintings are also, for contemporary readers, allusive and dense. The abrupt transition from Orpen's framing narrative to Qing's discourse is one of the striking features of the text. Where Orpen's narrative is anecdotal and covers a historical time period of a few weeks, Qing's enigmatic stories traverse time and space in sudden leaps. Some sense of Qing's narrative style seems to emerge from the text even though his stories have been heavily mediated by editing and translation: unlike his contemporaries Wilhelm Bleek and his sister-in-law Lucy Lloyd, the collectors and translators of |Xam folklore, Orpen does not attempt to follow the literal word order of the stories in which Qing told them but presents them in grammatically regular English. Qing, in any event, seems to have told the stories in his adopted tongue, SePhuthi (Wright \& Mazel 2007: 12), rather than in his native language (Solomon 2007: 159). His words were translated into English or Sesotho for Orpen by 'a Sotho- or Xhosa-speaking interpreter'. 9 Part of the uncanny quality of the stories resides in the way they simultaneously capture the resonance of $19^{\text {th }}$-century San storytelling and remind us of the disjunction between a hypothetical original San context and written and translated folklore. We have immediate access to the stories and yet they are, in some sense, irretrievably absent.

The text does not tell the reader how Qing told the stories so as to allow for their translation and transcription. The general consensus is that Orpen provides summaries of Qing's stories from his field notes (Lewis-Williams 2013: 79). It is true that the stories are much more compressed than the narratives of the contemporaneous Bleek and Lloyd collection, excluding the repetition and circularity that accompanies the stories in that collection. On the other hand, Qing's stories seem to contain elements - logical and temporal leaps, strange turns of phrase, obscure details - that one would expect to have been omitted from a simple summary. Orpen himself implies that he tries to capture as much as possible of the original, 'I shall string together Qing's fragmentary stories as nearly as I can as he told them to me. I noted them down from him then 
and since; I only make them consecutive' (1874: 3). Whatever the process of narration, translation and recording, Qing would clearly have had to radically adjust his storytelling technique to suit the situation. Orpen himself does not entirely appreciate these efforts, judging the stories as 'imperfect' and attributing their faults to Qing's youth and 'to his not having learnt them well' (1874: 3), an assessment echoed by Bleek (Orpen 1874: 12), who does caution, however, that we have access to Qing's stories only 'through the medium of an imperfect interpretation'. It is difficult to assess Qing's qualities as a storyteller from the translated stories in the Orpen essay in the same way that we can identify the distinctive qualities of each of the |Xam storytellers (see Hewitt 2008: 193-203). Nevertheless, the manner in which Qing's stories deploy plot, episode, characterisation and concrete detail suggest that Orpen somewhat underestimates his skill as a storyteller. It is possible that his evaluation also reveals some insecurity about the value of the materials he offers to the world of scholarly experts to whom he defers (1874:2). More importantly he exhibits alack of understanding of theplasticand protean nature of San storytelling. His comments imply that stories are learnt by rote and that their quality depends on their faithfulness to original versions. Qing's stories, Orpen asserts, 'may be corrected if heard from other Bushmen of the same race in Basutoland, Kafirland, \&c., or they may be different from those of other Bushman tribes' (1874: 3). This implies that differences, if they exist, should be attributed to communal tribal and cultural variation rather than to individual storytelling style, performative context or the slippery nature and multivocality of narrative discourse itself. If a story differs from the generic version that is regularly told within a specific cultural area then the storyteller must have erred and the story needs to be 'corrected'.

Neither Orpen nor Qing has the last word in the text. This is left to the expert, the celebrated linguist and collector of |Xam folklore, Wilhelm Bleek, who was asked by the editor of the CMM, Roderick Noble, to comment on Orpen's article (Bank 2006: 305). Importantly, though, another voice, that of Bleek's |Xam San informant, Dia!kwain, surfaces in the course of his appended 'remarks'. Bleek asks Dia!kwain to comment on Orpen's rock art copies, with far reaching consequences, both for the interpretation of rock art and for the genesis of the Bleek and Lloyd collection itself; Dia!kwain's comments about rainmaking in relation to the paintings opened up a new line of enquiry with regard to |Xam belief and practice. Andrew Bank (2006: 304-11) observes, though, that Bleek used Dia!kwain's comments with some licence in his remarks, with the result that it is not always entirely clear what can be attributed to Dia!kwain and what to Bleek himself. ${ }^{10}$

The content and register of Orpen and Qing's contributions to the final text are cultural and cognitive worlds apart; there is a radical alterity that is at the centre of the text. The $C M M$ article is polyphonic, containing multiple voices, not deliberately as in the craft of the $19^{\text {th }}$ century novelists Mikhail Bakhtin (1981) celebrates, but in the revealing ways in which the colonial text fails to contain its contradictions and speaks in multiple registers. Orpen's own writing is heteroglot: he speaks simultaneously as a settler, agent of British power, native sympathiser and as a researcher and scholar. Although Orpen does not emphasise his own standing as a scholar in the $C M M$ article, he discovered the first dinosaur outside Europe and had published a history of 
the Basotho before he turned 30 (Bank 2006: 304- 5). He also pursued botanical and geological studies (Orpen 1964: 6). Scholarly pursuits came naturally to him, coming as he did from an educated family; his father, a medical doctor, was 'a Hebrew and Greek scholar'(Orpen 1964: 26).

Qing answers questions and tells stories in the text but also seeks to explain and interpret, trying to gauge Orpen's levels of comprehension and his intentions as he does so (Challis 2005). In drawing upon his cultural repertoire, he speaks to an absent San audience even as he addresses the administrator-scholar and the SePhuthi and Sesotho-speaking interpreters, who would have been familiar with oral performance but probably less familiar with the sort of content that Qing delivers. If there were BaPhuthi among his audience, though, it should be remembered that the BaPhuthi incorporated a strong San element (Jolly 1995: 71; Mokhanya 2008: 34-9; King 2014: 133-7). Some of his audience, at least, might then have had some familiarity with his stories. It is possible that the close relationship between the San began as early as the $17^{\text {th }}$ century when the BaPhuthi crossed the Drakensberg Escarpment into present-day Lesotho' (King 2014: 109). The famous BaPhuthi leader, Moorosi, whom Orpen knew very well, ${ }^{11}$ was himself reputed to be half San (Jolly 1995: 71), 'afforded protection to numbers of San communities' (Wright \& Mazel 2007: 93) and had two San wives and children by them (Mallen 2008: 101; King 2014: 132).

By the $19^{\text {th }}$ century the two communities lived together in Nomansland, and 'The San began to adopt some Phuthi culture and the Phuthi adopted some San practices' (Mokhanya 2008: 37); the latter included 'a knowledge of rock art production' (King 2014: 135). The San were 'key allies' for the BaPhuthi in the war they fought against Britain in 1879 and 'some BaPhuthi continued to maintain close connections with Bushmen' even after the dispersals that followed the war (King 2014: 200-1).

\section{Actors}

There are many different actors present, sometimes peripherally, in Orpen's article. There are the white men, the two most prominent among them, Orpen and Grant, typifying the colonial project but also its fissures and contradictions. Orpen, as we have seen, was a colonial official tasked with the expansion of British control but he was also a man and a scholar who sympathised with and possessed an interest in indigenous people, languages and culture, a man open to some extent, therefore, to the decentring encounter with the Other. Orpen's Reminiscences (1964) show that he related to Dutch or Boer people as easily as he did to English speakers. He was touched by the fact that he 'an Englishman, should be so generally ... asked for by an absolutely Dutch community' to serve as the landdrost for Winburg (Orpen 1964: 223-5). While he vigorously opposed the British abandonment of control of the Free State, he went on to serve the Orange Free State republic energetically and played a central role in drawing up and defending its liberal and republican constitution (Orpen 1964: 1, 203-7; King 2014: 352). He understood the plight of the Griqua (Orpen 1964: 107, 124) and their need for land and security. He revised his initial views of the Basotho and became an ardent admirer of their leader, Moshoeshoe. 
Significantly this change of mind was induced by conversations with the missionary to the Basotho, Eugène Casalis, and the perusal of 'documents and books [that] upset all my ideas about the country and produced a great change in my opinions about men and things' and led him to conduct further historical 'researches' (Orpen 1964: 215). 'From this revelation,' notes King (2014: 354) 'stemmed Orpen's lifelong commitment to writing southern African history from all sides, especially obtaining first-hand accounts from British, Boers, and black Africans'.

The combination of colonial administrator and scholar of indigenous culture, found in Orpen, was not the norm but was also not uncommon. Patricia Vinnicombe (2009: 105-25) runs through a whole gamut of amateur rock art enthusiasts who straddled in one way or another this divide. She notes of the colonial secretary, Donald Moodie, for instance, that it was 'ironically incongruous' that he pursued enquires into the origins of the San in 'his leisure hours in Natal' while planning military action against them in the course of his official duties. The German missionary Leonhard Schultze, who collected Nama stories while accompanying a German expedition of extermination against the Nama, is an extreme example of this fracture (Wittenberg 2012). However, many other colonial officials were in the same ambiguous position, notably Louis Anthing (De Prada-Samper 2012a), who administered the frontier zone but also tried to prevent the genocide conducted against the San there.

Orpen sympathises with the natives, speaks an African language and prides himself on establishing cordial relations with them. He is interested in their culture, an interest which simultaneously reaches out to the Other and constitutes an integral part of the colonising project in which the Other is subjugated. We remember here Edward Said's point about the relation between knowledge and power. Orientalism was valuable less as 'veridic discourse' asserts Said (1991: 6), than as 'a Western style for dominating, restructuring, and having control over the Orient'. In Africa, ethnography operated in a similar way. At the same time, though, the engagement with the ethnographic Other potentially weakened ideologies of western superiority and exceptionalism. As Pierre Bourdieu (2001: 3) observes, 'a detour through an exotic tradition is indispensable in order to break the relationship of deceptive familiarity that binds us to our tradition'. The coloniser and the colonised were changed forever by the colonial encounter in unpredictable and complex ways, both were reconstituted as new subjects (Bhabha 1983: 19).

The fact that Qing 'had never seen a white man but in fighting' (Orpen 1874: 2), must have touched Orpen deeply for he had himself been involved in a tragic skirmish nearly 20 years earlier with a group of San; 18 people had died, including 15 San men (Orpen 1964: 27283; Lewis-Williams 2003: 99-102). It transpired later that the local commandant had persuaded Orpen of the necessity of the action because he had wanted an opportunity to capture San children (Orpen 1964: 280-3). Orpen was vehemently opposed to the practice of capturing and indenturing San children. He was appalled to hear of the activities of Daniel Pietersen, for example, who 'had been in the habit of murdering Bushmen and driving a large trade in the children, often selling a child for a cask of brandy ...' (1964: 
259). He was prepared to put both his 'popularity' with the Boer farmers and his own safety on the line to fight the traffic (1964: 302-6), in one case mounting an expedition into Zululand to do so (1964: 311-24). The unpopularity he gained through these efforts was later replicated when he was seen to side with the Basotho in their land claim disputes with the republic; he was arrested and expelled from the Orange Free State in 1858 (Eldredge 1988: 193; King 2014: 355-6).

If Orpen exemplified one sort of colonial figure, that of scholar and ethical coloniser, the 'short-tempered' career officer James Grant (Lewis-Williams 2003: 19) exemplifies a more typical figure in the Victorian period of British imperialism. Grant's sense of racial superiority made him distrust the information given him by Basotho informants (Mitchell \& Challis 2008: 402, 422). He refused on racial grounds 'to get a permit from a Hottentot magistrate' to acquire ammunition. While Orpen had a sense of fairness that included 'blacks and whites' in the colonial dispensation (Orpen 1964: 135; King 2014: 352), Grant's view of black people was unremittingly negative and represents the crude racist side of colonialism. The Basotho are described more than once in his diaries as 'brutes' and as 'dirty' (Mitchell \& Challis 2008: 421, 425). Grant was particularly offended by their smell (Mitchell \& Challis 2008: 421, 422). He dislikes Orpen's liberal racial attitudes: 'Orpen is too easy with them [the Basutos] altogether' (Mitchell \& Challis 2008: 421). He attributes Orpen's failure to think about leaving Grant's mail behind for him to the fact that he was ' $[\mathrm{m}]$ ost probably dreaming away about his beloved niggers ...' (Mitchell \& Challis 2008: 445). Grant seems to have had more faith in San guides than he did in the Basotho, however, evincing relief when Qing finally arrived (Mitchell \& Challis 2008: 429) and setting more store by his reading of tracks than anyone else's (Mitchell \& Challis 2008: 438). More surprising perhaps, was his reaction to the rock art he saw: 'The paintings, many of them capitally done ... were quite artistic. The colours were most brilliant...' (Mitchell \& Challis 2008: 434). Perhaps some of Orpen's enthusiasm rubbed off on him after all. This was a time, it should be remembered, when popular opinion considered the rock art as primitive, 'obscene' and 'grotesque' (Barnard 2007: 32).

Off-stage, until later in Orpen's article, there is Wilhelm Bleek, curator of the Grey collection, a vast library assembled by the erstwhile governor of the Cape, George Grey, and a linguist and cultural evolutionist with close ties to the European intelligentsia - a man, as Andrew Bank's (1999, 2006) work has shown who was ambiguously positioned as an ideologue of scientific racism, on the onehand, and susceptible to thetransformative impact of his |Xaminformants, on the other (see Wessels 2008) - and also Dia!kwain, one of a group of |Xam prisoners who were released into Bleek's custody to act as language and cultural informants with governor Henry Barkly's permission (Bank 2006: 69-73). Dia!kwain had been imprisoned in the Breakwater prison for killing a farmer in self-defence (Bank 2006: 218-23). Bleek would become the first commentator on Qing's narratives while Dia!kwain would become the first interpreter of the rock art copies Orpen sent to Cape Town.

Present also, although on the periphery, are the Basotho auxiliaries, some of whom also spoke Sephuti, the hybrid Nguni/Sotho tongue in which Qing told his stories. And finally there is Qing himself, a San man living with the BaPhuthi - 'The language he spoke best besides his own was 
that of the "Baputi"' (Orpen 1964: 2) - as noted above a group with strong ties with the San, some of whom perished fighting in the BaPhuthi cause against the British in 1879.

A combination of military and ethnographic imperatives produces the Qing-Orpen encounter and removes Qing's storytelling from the realm of everyday storytelling practice. It is storytelling of a particular kind; it occurs in the context of an ethnographic encounter, initiated by Orpen but enacted by Qing. And it is made possible in the first place by war. The power relations that encompass the meeting are clearly unevenly distributed: Orpen represents an imperial superpower at the apogee of its hegemony while Qing is a refugee of sorts. Nevertheless, Qing is not powerless. He retains a certain power over representation, both in his own words and the words he elicits from Orpen. The core of the $C M M$ article consists of Qing's explanations of paintings and stories. The major force of representation is his, a power that has increased over time as his words are pored over and interpreted, eliciting ever-freshinsights andlines of enquiry.

Qing makes an impact even before he arrives, by his very elusiveness and the significance of what he has to offer the expedition. It is notable that Orpen depicts Qing as an individual rather than as a type. Qing comes alive in Orpen's description of him: 'he became a favourite, he and his clever little mare, with which he dashed and doubled among the stones like a rabbit ...' (Orpen 1874: 1). As will occur in many subsequent ethnographic encounters, Qing both bears the projection of San-ness and employs it for his own purposes. He stages a performance of storytelling even as he tells stories, judging when the time and setting is right: 'When happy and at ease smoking over campfires ...' (Orpen 1874: 2). He chooses what to narrate and, we can assume, what to conceal. $\mathrm{He}$ also, it is evident, was reading Orpen as much as Orpen was reading him, registering Orpen's incomprehension of what he was seeing and hearing and trying to compensate for this lack of understanding with his explanations and stories (Challis 2005:14-8).

\section{War, Contact, and Identity}

Orpen and Grant's combined force brings together men from disparate communities: European settlers in southern Africa, men from Britain, speakers of Sesotho, isiXhosa and SePhuthi from Nomansland, and of course a San man. The enlistment and collaboration of locals was a recurring feature of colonial conquest and control as Europeans themselves were generally thin on the ground. Qing's role as an indigenous scout is replicated in the use of Khoe auxiliaries in the eastern Cape, for example, and, a century later, in the use of San trackers in the war in Angola and Namibia.

The coming together to smoke and tell stories around the campfire occurs in a war setting that is part of a broader global colonial context characterised by violence. The audience for Qing's cultural performance consists only of soldiers and policemen. There are no women and children to hear the tales in which women and children feature prominently, although, as we will see, Qing's wives feature earlier in the text when the winning of their trust is seen as a significant step in acquiring Qing's services (Orpen 1874: 2). Qing tells his stories in the context of the conflict with the Hlubi but violence, of 
course, was nothing new to the San or to the Drakensberg-Maloti region. Tensions between the Boers in the Free State and the Basotho to the west periodically spilled over into armed conflict; the BaPhuthi among whom Qing lived were frequently involved in armed conflict. They bravely fought the British in 1878 and 1879, a war in which Grant participated (Mitchell \& Challis 2008: 400), before being brutally crushed. Orpen sympathised with the BaPhuthi and their leader Moorosi, producing a memorandum at the conclusion of the fighting with the aim of showing that 'Moorosi's lands had been unfairly usurped' (King 2014: 359). ${ }^{12}$

South of the Maloti lay the eastern Cape with its history of a century of armed conflict with the Cape Colony. Basotholand would become a British protectorate rather than succumb to the Boers but would then go to war with Britain - the Gun War of $1880 / 81$, in order to preserve its sovereignty when Britain treated the territory as a fully-fledged colony (Eldredge 1993: 165-70). Grant (Mitchell \& Challis 2008: 400) fought in this war as well and Orpen played a role in brokering a peace settlement at its conclusion (King 2014: $360)$.

The San of the Drakensberg foothills to the east had been coming under unbearable pressure from colonists and Bantu-speaking pastoralists for decades before Qing and Orpen's meeting. British commandos, had until very recently, pursued San raiders in the Drakensberg foothills below the escarpment (Wright 1971). The San strongholds in the highlands that were visited by Orpen had come under similar pressure. John Wright and Aaron Mazel (2007: 12) conjecture that Qing had survived an attack by forces from Natal that destroyed his band in 1869. Just two years before Orpen and Qing's stay in Sehonghong, a group of Basotho had killed a band of San headed by Soai, after whom the place is named, just down river from the shelter in reprisal for cattle theft (Mitchell 2010: 156-7). Qing might have himself been a victim of this attack and have sought refuge with the BaPhuthi after it (Jolly 1995: 71). In 1878, five years after Orpen and Qing's encounter, the Basotho formally occupied the highlands and the shelters of Sehonghong and Melikane would cease to be home to San bands, although sporadic San occupation of Sehonghong appears to have continued until at least the 1890s (Mitchell 2010: 162-5).

The overall result of these events was not the extermination of the San but their assimilation into other groups of people, the gradual extinction of the San language of the Drakensberg and the suppression, but not the complete erasure, of San identity in the area. A considerable body of writing, chiefly by historians and archaeologists, shows that the $19^{\text {th }}$ century was characterised by a great deal of mixing between San and Sotho and Nguni groups. The ability of the San to merge with their neighbours was made easier by ancient relationships between agro-pastoralists and foragers and by long histories of economic, social, cultural and economic hybridisation. In the $19^{\text {th }}$ century these interactions included political alliances and economic networks. Wright describes, for example how in 1829, 'Andrew Geddes Bain (1849: 115-8) encountered a group of some 30 families of Bushmen, "intermixed with Caffres" (Xhosa speakers), on the lower Mzimvubu River'. 
Wright deduces that 'they were producing ivory to trade either southwards to the Cape market or northwards to the small groups of British hunter-traders who had been operating from Port Natal since 1824' and goes on to remark that 'from very early on, these Bushmen or San, were seen by the Boers as having been involved in a network of raiding and trading alliances that extended from southern Natal $300 \mathrm{~km}$ or more to the north-eastern Cape colony' (2007: 121-2).

The Mfecane upheavals and the advent of Europeans in the eastern Cape, Natal, and the Orange Free State made the situation in the $19^{\text {th }}$ century particularly fluid but the involvement of Bushmen with other groups in the Drakensberg area goes back more than a thousand years (Jolly 1994; Francis 2007). Michael Francis goes so far as to argue that the Drakensberg Bushmen, broadly referred to by the people in the area as the Abathwa, should be seen as an aboriginal component of the Nguni peoples of the region rather than as an entirely distinct people and conjectures that the infusion of San words into the Bantu language(s) of the migrants from the north might be considered as the defining event in the creation of the Nguni language family (2007: 213). Peter Jolly concedes that conflict often characterised relations between Bantu ${ }^{13}$ and San (1994: 38) but notes that this history has to be balanced with one of trade, intermarriage, and ritual cooperation (1994: 79). He observes that both Bushman and Nguni/Sotho societies were open to outsiders, a factor that facilitated incorporation and admixture.

The San position in relation to the other peoples of the region in the $19^{\text {th }}$ century was not simply one of weakness in which they were sheltered by more powerful neighbours. The BaPhuthi at one time were said to have lived among the Bushmen rather than the other way round and it was only later that 'the Phuthi, whom they [the San] had previously considered their servants, had now become their masters ...' (Vinnicombe 2009: 87-8). In the eastern Cape, the San obtained guns and horses from Xhosa neighbours in exchange for rainmaking and curing services and prospered in the wider economy. Traces of these complex sets of relationships persist to this day (Prins 1996: 138-52). Orpen himself writes of San/Sotho relationships: 'These Bushmen were formerly very numerous, and the Basutos say they lived on good terms with them and among them before the game country became occupied' (1874: 3).

One of the main projects of rock art research has been to learn something of the complex history of the San and their relations and interactions with other groups over a long period of contact from the rock art itself, thereby contributing 'towards the writing of socially engaged and socially relevant histories of the past ...' (Smith 2010: 345; Blundell 2004: 53-75; King 2014: 67-8). Jolly (1995: 68) argues that the 'symbiotic contact between certain south-eastern San and Nguni and southern Sotho communities resulted in the adoption of some of the ritual practices and religious concepts of black farmers by the San, with the consequent expression of these rites and concepts in the rock art', a view that informs his interpretation of the therianthropic images traced by Orpen. Sam Challis (2009: 104-6) reads the rock art images of baboons and horses in the $19^{\text {th }}$ century 
eastern Cape as a product of the beliefs and 'new identity' of the 'creolised' cattle-raiding AmaTola, who included San, Khoe, runaway slaves, and people of Bantu descent in their ranks. Lara Mallen (2008: 5) suggests that a distinctive variety of rock art in Orpen's Nomansland area can be 'understood in terms of the complex interaction between the many inhabitants of Nomansland over the last 500 years' and of identity formation in a context of multi-ethnicity. Blundell (2004: 113-9) argues that another distinctive body of painting in Nomansland was made by non-San living with a group of predominantly San people under the leadership Nqabayo in the mid-19 ${ }^{\text {th }}$ century.

All of this points to a complex picture of cross-cultural influence, hybridisation and creolisation. It is true, nevertheless, and Qing's case underlines this, that despite '1,800 years of interaction' (Mitchell 2009: 25) and various degrees of hybridisation in the area between San, Khoe, Bantu, and Europeans, distinct identities and lifeways persisted even as people interacted in various ways, both hostile and friendly. Orpen's encounters with San groups in the Free State in the mid-19 ${ }^{\text {th }}$ century suggest too that San groups, distinguishable by culture and self-identity, lived among the Sotho, who sometimes feared them (1964: 282), or on European farms and also in Zululand (1964: 315). Blundell (2004: 73) observes that 'the nature of interaction between San and Bantu speakers' varied greatly in different areas and across time, a point borne out in the discussion of the rock art outlined in the previous paragraph which suggests that a continuum of contact possibilities and types existed in the Drakensberg-Maloti and Nomansland. These include a high level of cultural subordination to the Bantu (Jolly 1995), creolisation and multiethnicity (Mallen 2008; Challis 2009) as well as co-habitation, but with a clear division of identity and culture (Blundell 2004), a situation that probably also prevailed in parts of the Free State (Klatzow 2010) and which also, to some extent, describes the position of Qing and his wives among the BaPhuthi. Gavin Whitelaw, drawing on archaeological, ethnographic, and $19^{\text {th }}$-century testimonies from Nguni informants, argues that the general pattern of interaction between Nguni and San over the centuries was one that involved both cooperation and difference and subordination, with the ambiguous positioning of the San between nature and culture (2009: 143) making them sought after as diviners and rainmakers.

Peter Mitchell (2009) agrees with Jolly $(1994,1995)$ that the paintings copied by Orpen include some Bantu elements. This holds for thestories, too: the churning of medicinein a pot in thestory of the creation of the eland (Orpen 1874:4) is a case in point (Mitchell 2009: 22). Nevertheless, in Mitchell's view, the art is essentially San and has to be understood primarily in terms of San belief systems and cultural practices, a view that is supported by the dominant shamanistic interpretation of the same images by David Lewis-Williams and his collaborators (see for example, Lewis-Williams 1981, 2003; Lewis-Williams \& Dowson 1989), which hinges on a distinctively San spirituality and collates Qing and Dia!kwain's comments on Orpen's copies with San ethnography from the Kalahari and material from the Bleek and Lloyd archive. Anne Solomon's (1997: 199, 2007) contention that much of the rock art depicts the world of the dead rather than trance practice and visions is also based on her reading of the mythology that 
appears in Orpen's article and in the Bleek-Lloyd collection rather than on the influence of Bantu culture on the art. Mitchell (2009) points out that for much of the precolonial period Bantu-speaking agro-pastoralists were confined to warmer areas of the country because their crops were intolerant of cold conditions. The settlement of the Natal Drakensberg foothills by Nguni-speakers occurred in the $19^{\text {th }}$ century as part of a colonial strategy to create a buffer zone between European farmers and San raiders (Mitchell 2009: 18) while the settlement by the Basotho of the area through which Qing led the expedition only occurred in the late 1870s. This does not mean, of course, that the Drakensberg-Maloti San were isolated. The archaeological record, notes Mitchell, demonstrates that plants such as tobacco and cannabis, domestic animals, metal, pottery and jewellery were imported into the area over long periods of time. Mitchell and Hudson (2004: 43-6) conjecture that the plant canna, which features prominently in Qing's stories, might have been psychoactive Sceletium brought in from parts of the country that lay far to the west. Less tangible elements of culture, including stories, no doubt followed the same trade routes.

The Orpen-Qing text seems to support Mitchell's arguments about the relative autonomy of the Maloti San and the primarily San nature of the art. Qing is identified as a Bushman by other African groups in Nomansland: 'In inquiring for efficient scouts I had heard that one Bushman, named Qing, a couple years ago escaped from the extermination of their remnant of a tribe in the Malutis ...' (Orpen 1874: 2) He self-identifies as a Bushman, using the first person plural at several points in the text, as in 'Cagn made all things, and we pray to him'.

His San identity is underscored by the fact that he speaks a San language, knows the countryside around Sehonghong intimately in the period before its occupancy by agro-pastoralists, and, of course, possesses a first-hand knowledge of San rock art and oral literature. His stories offer an account of the mythological period of the first times that is unified and coherent and which strongly reflects a hunter-gatherer economy and culture, just as do the narratives of the Bleek and Lloyd collection. This does not mean that Qing did not know other stories - he must have heard BaPhuthi narratives for a start; after all by the time Orpen met him he was 'a "San man in a Bantu-speaker world" [who] had become proficient in SePhuthi and Sesotho' (King 2014:109).

Nor does the unity and internal consistency of the stories mean that the outside world is excluded from them. Mark McGranaghan's analysis of 'the way in which |Xam individuals constructed "alien" identities' (2014: 670) is instructive in this regard. Such an analysis seems suited to Qing's account of the Qobé giants and 'Qwanciqutshaa, the chief, [who] used to live alone', for example (Orpen 1874: 6). Narrative, McGranaghan (2014: 670) reminds us, is an important way 'in which indigenous populations themselves understood and manipulated their historical interactions with "Others". Mythology, after all, does not exclude history; it 'is a type of speech chosen by history ...' (Barthes 1986: 110). 


\section{Smoke and Stories}

Orpen gains the trust of Qing's wives as part of his strategy to acquire Qing's services by giving them tobacco: 'I succeeded in impressing Qing's wives favourably ... I gave them a liberal supply of tobacco' (1874: 2). A little later Qing himself is prevailed on to share his stories and cultural knowledge when relaxed and smoking: '[W]hen happy and at ease smoking over camp-fires, I got from him the following stories and explanations of paintings ...' (Orpen 1874: 4). This was not the first time that Orpen had used gifts of tobacco to win the trust of San people. At the outset of his ill-fated mission to evict a group of San from a farm, mentioned earlier, he tries to win over the head man with a gift of tobacco: 'I handed him a cigar which I had purposely brought, having heard that tobacco was the best and almost infallible means of opening amicable relations with Bushmen' (Orpen 1964: 275). In this case it failed spectacularly and bloodshed followed. Orpen had more success later when he was investigating the kidnapping and trafficking of San children in Zululand. He calms a San man who tried to flee when he saw a white man by giving him tobacco (1964: 321). Not only Europeans used tobacco to facilitate relations with the San. A Sotho chief told Orpen that his people "were, from of old, deadly afraid of Bushmen and avoided by all means any row with them, conciliating them to the utmost of their power and making them presents, especially of tobacco' (1964: 283).

Smoking creates trust and conviviality. At one point Grant and Orpen signal the restoration of 'peace and amity' between them by smoking together (Mitchell \& Challis 2008: 427). Tobacco is a substance that is shared and which eases social interaction. It possesses a seductive levelling effect, especially when coloniser and colonised smoke together. But tobacco, of course, is also an agent of 'worlding' (Spivak 1999: 114), drawing people into globalised circuits of power, production and consumption. Tobacco exemplifies the consensual side of colonial power: it insidiously inserts itself into everyday practice through the soft, seductive violence of its addictive power. It is part of the peaceful repertoire of trade goods that eases the penetration of European power. But it is intimately linked, too, to cruder forms of overt violence and coercion: slavery, plantations, environmental despoliation, dispossession, and war. Tobacco was routinely issued to soldiers during campaigns; it suppressed hunger, increased endurance and lifted morale.

Tobacco had become part of San culture too (see Sampson 1993). The colonised were not simply passive victims of power; they selectively appropriated the culture of the colonisers: maize, Christianity, guns, horses, tobacco. Tobacco forms part of San self-identity; //Kabbo, the celebrated |Xam storyteller, designates the |Xam as 'smoking people' (Bleek \& Lloyd 1911: 303). Grant notes that the San inhabitants of Sehonghong cultivated nothing but tobacco (Mitchell 2010: 162).

As observed earlier, the campfire at which Qing smokes and tells stories in the evening is not the campfire of the San band, with people of different sexes and ages sitting around it, but the campfire of soldiers; it is also the campfire of the ethnographic encounter. Justine Wintjes observes in relation to rock art, but her comments apply to some extent also to stories, that this meeting happened at: 
a time of transition from a living painting culture to a dead one, from originals to copies, from paintings to attempts to explain them, and from a world in which the art was created by and for members of hunter-gatherer communities to one where it was viewed by outsiders as an enigmatic trace of a lost way of life. (2011: 22)

The stories and art in the Qing-Orpen text belong largely to an independent San world but the text itself is produced at the time when the San 'were absorbed into other communities' (Whitelaw 2009: 139). Orpen's encounter with Qing occurs during this period of transition and is itself a defining moment marking this transition: Drakensberg San literature enters a European language and medium, the written article, at the very moment that this literature disappears (or seems to disappear) as a cultural practice. Orpen records it, self-consciously aware of a time and tradition that is passing, but unaware perhaps that his actions and his writing are also constitutive of this change. He records, copies and preserves, helping to rescue something of the past but also missing something of the present and the future. The same ambiguity attends the Bleek and Lloyd collection. The archive conserves and eulogises, consigning San culture to tradition and the past as it rescues it from the annihilation of the colonial occupation. It is evident from the vantage point of the present, though, that aspects of San culture and identity survived in different forms in both the northern Cape and Drakensberg-Maloti areas in ways that neither Bleek nor Orpen could have anticipated.

Today we understand better that the San, like everyone else, are not a people of the past. At the same time, though, we should not underestimate the genocidal violence visited upon them and the consequences of the loss of their land. The habitat that sustained the wild animals and plants, which in turn supported a hunter-gatherer economy, was devastated. Bands and families were broken up and individuals scattered among the farms as labourers in some areas or among independent small farmers in others. San languages and social and economic systems disappeared, albeit more slowly than previously thought, and not without trace, for the San have made a major contribution to the hybrid cultures and societies of the region.

Bleek's most senior informant, //Kabbo, displays an acute understanding of the threat facing his people when he discusses the links between smoking and storytelling in a piece first recorded in Lucy Lloyd's notebook in 1873: 'The Flat Bushmen go to each other's huts; that they may smoking sit in front of them. Therefore, they obtain stories at them; because they are used to visit; for smoking's people they are' (Bleek \& Lloyd 1911: 301-3). Smoking here signifies equality, ease and communication. //Kabbo contrasts the reciprocity of storytelling in an indigenous context, symbolised by the sharing of tobacco, with the sterility of telling stories in an ethnographic one; he laments his position as an informant in Bleek's household and bemoans the fact that he does not receive new stories in Cape Town: 
For, I am here; I do not obtain stories; because I do not visit, so that I might hear stories which float along; while I feel that the people of another place are here; they do not possess my stories. They do not talk my language; for, they visit their like. (Bleek \& Lloyd 1911: 300)

//Kabbo's words possess powerful literary qualities - a theme of loss, for example, and a critical dimension; the piece is about storytelling itself as much as it is about physical and social displacement. ${ }^{14}$ At the same time it should be noted that //Kabbo does not mean to produce literature here. Like his request for thread to sew on a button, recorded by Lloyd and converted into a poem by Stephen Watson (1991), this piece has been turned into literature by a series of moves involving translation, publication and reception. As Pierre-Philippe Fraiture notes 'every textual intervention about Africa is ... ideologically driven and results ... in "inventions", "parables", "fables" and "tales" (2013: 7). Africans like //Kabbo and Qing might struggle to recognise themselves and their art in these ideologically driven representations. //Kabbo's people, the |Xam, must assume their place in a taxonomy of ethnicities; they are Bushmen or San. Their dynamic performance art becomes timeless mythology. It is not surprising, given this history that the main thrust of //Kabbo's argument about storytelling has been largely ignored by scholars. The phrase 'stories that float from afar' has come to signify the ability of stories to transcend temporality and place, to speak to the modern world of inaccessible experiences from a time that has gone, along with the quagga. ${ }^{15}$ But //Kabbo mourns in this piece his inability to receive, transmit and perform stories when severed from a community of meaning, telling and interpretation. Stories might be able to float across time and cultures but they cannot retain their dynamism and their ability to generate new stories.

Where does the Qing/Orpen encounter fall in terms of //Kabbo's critique of ethnographic storytelling? Qing relates stories because he is prompted to do so by Orpen's questions. He has no control over the way in which his narratives will be translated, ordered, reproduced and consumed in the outside world. He is made to speak for a tradition and not, as Orpen does, for himself. In //Kabbo's terms his stories fall into the hands of non-smoking people. The stories generate academic writing and debates, chiefly about rock art, rather than new stories. Nevertheless, we should not forget, as suggested earlier that Qing still enjoys a certain power over representation. It is also likely that when he told the stories at the campfire while smoking he did so to an audience that was not confined to the European interlocutor. His audience was, to some degree, made up of 'smoking people' like himself, people who were used to telling and listening to stories in a context of oral performance.

We might never know exactly how San stories have formed part of the web of narrative practice in the region although sociolinguistic and folklore studies will hopefully shed new light on the question. What we do know is that this is unlikely to have been the only time that Qing or his wives or the other San men and women who continued to inhabit the area told these stories to Sephuti or Sesotho speakers, including their own children. Afrikaans-speaking people continue to tell stories and possess cultural knowledge in the northern Cape that derive from |Xam tradition (Hoff 1998, 2007; Swartz, De Prada-Samper \& Winberg 2014; De Prada-Samper 2012b, 2014). Frans Prins' (1990, 1992, 1996, 2009) work on present-day people with San 
identities in the wider Drakensberg-Maloti region suggests that similar continuities exist in this area. The politics of power, dispossession and genocide ${ }^{16}$ that frames the Bleek-Lloyd project and the Orpen-Qing encounter has masked until recently the passage of the San to the contemporary, their ability to adapt, to integrate and to become modern historical subjects.

The home to which //Kabbo longs to return is also a world he has evoked in the tens of thousands of words he has already relayed to Bleek and Lloyd, but it is a world that is already literary rather than tangible. //Kabbo and his community have been displaced by settler invasions and his pursuit of a livelihood criminalised. The poignancy of the piece, underscored by longing, lies in the fact that //Kabbo can never really return home, as the tragic events that generally accompanied the return of Bleek and Lloyd's |Xam informants to the northern Cape reveal (Bank 2006). Home, in Homi Bhabha's (1992) unforgettable formulation, had been rendered unhomely, invaded by history. Qing, likewise, cannot return to the world of his boyhood, invoked in the symbolic worlds of the stories he tells and the paintings he discusses. Nevertheless, he and his descendants, and //Kabbo's descendants, will become integral to a new world, one which, as much as his stories of the first times, is still in the process of becoming.

\section{Conclusions}

The Orpen-Qing article is a key document. One should not underestimate the ideological capital that resulted from the study of rock art and mythology and folklore in the context of the new science of anthropology - the 'science of the West's Other' as Valentin Mudimbe (1988: 186) describes it - and its place in the constitution of European knowledge, identity and power. 'The very idea of modernity,' as Moran observes (2009: 127), 'is inseparable from the construction of the Bushmen'. Alan Barnard (2007) traces the history of the constitution of the San as an anthropological category, through travel writing to its consolidation in the latter part of the $19^{\text {th }}$ century with the work of Bleek and Lloyd. While Barnard (2007: 37) claims that 'Orpen's record is not to the high standard of Bleek', it has been as central to this process as the Bleek and Lloyd archive, largely because of its place in rock art interpretation and the understandings and representations of the San that have accompanied this interpretation. It is difficult to predict how scholarship on the San will change and how San identifying people will mobilise themselves politically and culturally in the future, but it seems certain that readings of the Orpen-Qing text will continue to play a central role in San studies For Orpen himself, if we can judge from the title of the $C M M$ article and the place he accords to narratives in it, the stories were more important than the comments on art. The continued study of these stories, in my view, still has a lot to offer San scholarship, with regard to both better understanding the stories themselves and their connection with the present. Rock art production all but ceased at the time of Qing's encounters with Orpen but stories have continued to be told in the Drakensberg-Maloti area.

Scholarship necessarily hides as much as it reveals. Academics have concentrated on selected parts of Qing's testimony. Along with other complex oral literary genres from around the world, San stories are usually categorised as myth and folklore, whether they 
come from the Drakensberg, northern Cape, or the Kalahari. The West has literature while 'traditional, pre-logical' cultures such as the San possess myths and folklore. The idea of western cultural superiority has required the maintenance of this distinction since the category literature serves to reinforce the 'the myth of the myth of the mythless society' (Nancy 1991: 63). The challenge remains to find ways of reading texts like this, from the 'colonial library', in fresh ways so as to produce the sort of knowledge that does not 'repress otherness in the name of sameness, reduce the unknown to the already known, and thus fundamentally escape the task of making sense of other worlds' (Mudimbe 1988: 72-3).

Orpen chooses to emphasise the spontaneity and uniqueness of his encounter with Qing. He downplays the fact that he interviewed Qing again after their meeting in the Maloti and after he had become acquainted with Bleek's work (1874: 22). His account omits also any real discussion of the Langalibalele rebellion and fails to mention the tensions between him and Grant. This is not because he does not understand the import of history and politics; his other writings amply demonstrate this. But in this article his focus is on San rock art and stories. And given the paucity of this sort of record, we should be grateful that this should be the case. But we also need to recognise that the title of the article, Orpen's introductory comments, and Bleek's concluding remarks situate the encounter firmly within European history, scholarship and comparative mythography, and within a European ideology of vanishing peoples and evolutionism. Recent scholarship has demonstrated the ability of the Drakensberg-Maloti San to become part of the contemporary world through assimilation and hybridisation on the one hand and a consciousness of history and identity on the other, and it is from this perspective, of the 'vanishing present' (Spivak 1999), that we now need to learn to view the Orpen-Qing article.

\section{Notes}

1. The decision to use the term 'San' rather than 'Bushman' in this article is a matter of individual preference. The sources to which the article refers often use the term 'Bushman'.

2. Orpen states in his Reminiscences of Life in South Africa that he himself 'raised and commanded an army ... to co-operate against Langalibalele' (1964: 2). Grant was initially impressed by Orpen's friendliness and willingness to cooperate with him (Mitchell \& Challis 2008: 415) but later suspected Orpen of wanting to 'be commanding officer' (Mitchell \& Challis 2008: 424) and of turning Grant's 'squadron of Police into a support to a lot of dirty Basutos' (Mitchell \& Challis 2008: 425). Orpen appears to have given Grant the assurances he sought when confronted by him (Mitchell \& Challis 2008: 427). It is notable that Orpen does not refer to Grant in his article (1874) or his Reminiscences (1964). Rachel King (2014: 359) notes 'Orpen's insubordination to Grant' was later held against him when it was used 'as evidence against [his] competence' when 'in his tenure as British Resident, he illadvisedly called up Natal's armed forces to settle a relatively minor boundary dispute with Mpondomise or Mpondo residents'.

3. Grant also made overtures to procure Qing's services (Mitchell \& Challis 2008: 424). 
4. Orpen was critical of Stow's book, however, disagreeing with his thesis that African people, the Sotho in particular, were intruders who had displaced the San and claiming that most of Stow's information was second-hand (Eldredge 1988: 200)

5. The |Xam were a San people of the northern Cape. Bleek's informants were drawn from |Xam prisoners in Cape Town who were released into his custody with the governor's permission. They became part of his household in Mowbray.

6. Ironically, notes King (2014: 358-9), Orpen himself does not seem to have attributed much significance to his meeting with Qing. He does not refer to his encounter with Qing or to the expedition through the Maloti in any of his subsequent writing. King conjectures that this might have been due to the fact that he saw the expedition itself as a failure.

7. It is also true, though, that people claiming San ancestry continue to find significance in the paintings, and have even painted themselves, in the years since Orpen and Qing's meeting (see, for example, Mkhwanazi 2003; Lewis-Williams 2003: 49-51; Blundell 2004; Prins 2009; Wessels 2012; Sullivan \& Low 2014: 236).

8. Discussions of individual stories include Lewis-Williams (2003: 45-9); Lewis-Williams \& Challis (2011: 164-70); Lewis-Williams (2010: 8-15); Lewis-Williams (2013); Wessels (2014). Anne Solomon (1997, 2007) discusses Orpen's copies in relation to the whole cycle of stories.

9. Lewis-Williams (2003: 21) states that the stories were translated directly into English for Orpen, but since Orpen spoke a fair amount of Sesotho it seems likely that this language would also have been part of the translation process (McGranaghan et al. 2013: 140), a view to which Lewis-Williams, one of the co-authors of McGranaghan et al. 2013, seems to have also later subscribed.

10. Bank (2006: 308) claims that some of the views about the water-cow attributed to Dia!kwain in the $C M M$ article were Bleek's rather than Dia!kwain's. He bases this assertion on discrepancies between Bleek's notebook and his contribution to the CCM article and also argues that the sort of analysis ascribed to Dia!kwain was 'foreign' to him. Bleek, Bank notes, wanted to construct a narrative from Orpen's different copies while Dia!kwain himself was more concerned with 'telling a story based on a single feature identified in a single image'. Bank concludes that Bleek 'adopted considerable poetic licence, adding to Dia!kwain's comments about the dragging of the water-cow his own constructions of what this and the other images depicted' (2006:309).

11. Orpen wrote 'a genealogy and history' of the BaPhuthi which was taken 'directly from Moorosi himself' (King 2014: 129).

12. King describes this memorandum as 'the first and possibly most thorough chronicle of the BaPhuthi, their history, and their territories' yet produced, a position undoubtedly now held by her own work on the subject.

13.The widely used anthropological and linguistic term 'Bantu', notorious for its use as an apartheid racial category, was coined by Wilhelm Bleek (Bank 2006: 27).

14. See Helize van Vuuren (1994: 63) for a discussion of //Kabbo's piece as 'meta-discourse' and an example of 'indigenous literary theory'.

15.Lewis-Williams (2000) uses the phrase in this sense in the title of his collection of material from the Bleek and Lloyd collection. 
16. See Wright (1971) for a systematic account of the conflict with the San in Natal in Penn (1996, 2005) and Adhikari (2010) for accounts of the genocidal violence visited on the Cape San in the $18^{\text {th }}$ and $19^{\text {th }}$ centuries.

\section{Acknowledgements}

The research on which this article is based was conducted with the help of NRF funding for rated researchers. The article has been substantially improved by the detailed comments of the anonymous reviewers.

\section{Note on Contributor}

Michael Wessels teaches English literature at the University of the Western Cape (UWC). He has published

widely in the fields of San studies, orality, indigeneity, and South African literature. 


\section{References}

Adhikari, M. 2010. The Anatomy of a South African Genocide: The Extermination of the Cape San Peoples. Cape Town: UCT Press.

Bain, A.G. 1849. Journals of Andrew Geddes Bain. Cape Town: Van Riebeeck Society, quoted in J.B. Wright, 2007. 'Bushman Raiders Revisited', in P. Skotnes (ed), Claim to the Country: The Archive of Wihelm Bleek and Lucy Lloyd. Johannesburg: Jacana Press.

Bakhtin, M. 1981. The Dialogic Imagination: Four Essays. Austin: University of Texas Press.

Bank, A. 1999. 'Anthropology, race and evolution: Rethinking the legacy of Wilhelm Bleek'. Paper presented at a seminar at the University of the Western Cape (14 April) <http: www.history.und.ac.za/ sempapers/bank\%20on\%2obleek.pdf>.

Bank, A. 2006. Bushmen in a Victorian World: The Remarkable Story of the BleekLloyd Collection of Bushman Folklore. Cape Town: Double Storey.

Barnard, A. 2007. Anthropology and the Bushman. Oxford: Berg. Barthes, R. 1986. Mythologies (A. Lavers, trans). London: Paladin.

Bhabha, H. 1983. 'The other question: Homi K Bhabha reconsiders the stereotype and colonial discourse'. Screen 24(6): 18-36.

Bhabha, H.1992. 'The world and the home'. Social Text 31/32:141-53.

Bleek, W. \& Lloyd, L. 1911. Specimens of Bushman Folklore. London: George Allen.

Blundell, G. 2004. Nqabayo's Nomansland: San Rock Art and the Somatic Past. Uppsala: Uppsala University.

Bourdieu, P. 2001. Masculine Domination. Stanford: Stanford University Press.

Challis, S. 2005 “"The men with rhebok's heads; they tame elands and snakes”: Incorporating the rhebok antelope in the understanding of Southern African rock art'. South African Archaeological Society Goodwin Series 9: 11-20.

Challis, S. 2009. 'Taking the reins: The introduction of the horse in the nineteenth-century Maloti-Drakensberg', in P. Mitchell \& B. Smith (eds), The Eland's People: New Perspectives in the Rock Art of the Maloti-Drakensberg Bushmen. Johannesburg: Wits University Press.

De Prada-Samper, J.M. 2012a. 'The forgotten killing fields: "San" genocide and Louis Anthing's Mission to Bushmanland, 1862-1863'. Historia 57(1): 172-87.

De Prada-Samper, J.M. 2012b. "The ouma and the lion": A Contemporary |Xam tale of the upper Karoo'. Oráfrica 8:199-216.

De Prada-Samper, J.M. 2014. 'Continuity and change in the oral tradition of the Karoo', in L. Ntsebeza \& C. Saunders (eds), Papers from the Pre-Colonial Catalyctic Project, Vol 1. Cape Town: Centre for African Studies, University of Cape Town.

Eldredge, E. 1988. 'Land, politics and censorship: The historiography of nineteenth-century Lesotho'. History in Africa 15: 191-209.

Eldredge, E. 1993. A South African Kingdom: The Pursuit of Security in NineteenthCentury Lesotho. Cambridge: Cambridge University Press.

Fraiture, P.-P. 2013. V.Y. Mudimbe: Undisciplined Africanism. Liverpool: Liverpool University Press. 
Francis, M. 2007. 'Explorations in ethnicity and social change among Zulu-speaking San descendants of the Drakensberg mountains, KwaZulu-Natal'. Unpublished PhD thesis, University of KwaZulu-Natal.

Hewitt, R. 2008. Structure, Meaning and Ritual in the Narratives of the Southern San. Johannesburg: Wits University Press.

Hoff, A. 1998. 'The Water Bull of the |Xam'. South African Archaeological Bulletin 53: 109124.

Hoff, A. 2007. Medicine Experts and the |Xam San: The !Kwa-ka!gi: Ten who Controlled the Rain and Water. Cologne: Rüdiger Köppe Verlag.

Jolly, P. 1994. 'Strangers to brothers: Interaction between south-eastern San and southern Nguni/ Sotho communities'. Unpublished MA thesis, University of Cape Town.

Jolly, P. 1995. 'Melikane and upper Mangolong revisited: The possible effects on San art of symbiotic contact between south-eastern San and southern Sotho and Nguni communities'. The South African Archaeological Bulletin 50(161): 68-80.

King, R. 2014. 'Voluntary barbarians of the Maloti-Drakensberg: The BaPhuthi chiefdom, cattle raiding, and colonial rule in nineteenth-century southern Africa'. Unpublished $\mathrm{PhD}$ thesis, University of Oxford.

Klatzow, A. 2010. 'Interaction between hunter-gatherers and Bantu-speaking farmers in the eastern Free State: A case study from De Hoop Cave'. South African Historical Journal 62(2): 229-51.

Lewis-Williams, J.D. 1981. Believing and Seeing: Symbolic Meanings in Southern San Rock Paintings. London: Academic Press.

Lewis-Williams, J.D (ed). 2000. Stories that Float from Afar: Ancestral Folklore of the San of Southern Africa. Cape Town: David Philip.

Lewis-Williams, J.D. 2003. Images of Mystery: Rock Art of the Drakensberg. Cape Town: Double Storey.

Lewis-Williams, J.D. 2010. 'The imagistic web of San myth, art and landscape'. Southern African Humanities 22: 1-18.

Lewis-Williams, J.D. 2013. 'Qwanciqutshaa, a 19th-century southern San mythological being: Who is he and what does his name mean?' South African Archaeological Bulletin 68(197): $79-85$.

Lewis-Williams, J.D. \& Challis, S. 2011. Deciphering Ancient Minds: The Mystery of San Bushman Rock Art. London: Thames \& Hudson.

Lewis-Williams, J.D. \& Dowson, T. 1989. Images of Power: Understanding Bushman Rock Art. Johannesburg: Southern Books.

Mallen, L. 2008. 'Rock art identity in the north eastern Cape Province'. Unpublished MA thesis, University of the Witwatersrand.

McGranaghan, M. 2014. “Different people” coming together: Representations of alterity in |Xam Bushman (San) narrative'. Critical Arts: South-North Cultural and Media Studies 28(4): 670-88.

McGranaghan, M., Challis, S. \& Lewis-Williams, D. 2013. 'Joseph Millerd Orpen's A glimpse into the mythology of the "Maluti Bushmen": A contextual introduction and republished text'. Southern African Humanities 25: 137-66. 
Mitchell, P. 2009. 'Hunter-gatherers and farmers: Some implications of 1,800 years of interaction in the Maloti-Drakensberg region of southern Africa', in K. Ikeya, H. Ogawa \& P. Mitchell (eds), Interactions between Hunter-gatherers and Farmers: From Prehistory to Present. Osaka: National Museum of Ethnology.

Mitchell, P. 2010. 'Making history at Sehonghong: Soai and the last Bushman occupants of his shelter'. Southern African Humanities 22: 149-170.

Mitchell, P. \& Challis, S. 2008. 'A "first" glimpse into the Maloti Mountains: The diary of James Murray Grant's expedition of 1873-74'. Southern African Humanities 20: 399-461.

Mitchell, P. \& Hudson, A. 2004. 'Psychoactive plants and southern African hunter-gatherers: A review of the evidence'. Southern African Humanities 16: 39-57.

Mkhwanazi, Z. 2003. 'Winner 2003: Coming out'. Natal Witness 14 October.

Mokhanya, S. 2008. 'Mt Moorosi's past and present: Interpreting San rock art at MTM 1 site in the Quthing District of Lesotho'. Unpublished MSC thesis, University of the Witwatersrand.

Moran, S. 2009. Representing Bushmen: South Africa and the Origin of Language. Rochester: University of Rochester Press.

Mudimbe, V. 1988. The Invention of Africa: Gnosis, Philosophy and the Order of Knowledge. Bloomington: Indiana University Press.

Nancy, J.-L. 1991. The Inoperative Community. Minneapolis: University of Minnesota Press.

Orpen, J. 1874. 'A glimpse of the mythology of the Maluti Bushmen'. Cape Monthly Magazine 9: 1-13. Orpen, J. 1964 [1908] Reminiscences of Life in South Africa from 1846 to the Present Day. Cape Town: Struik.

Penn, N. 1996. “Fated to perish”: The destruction of the Cape San', in P. Skotnes (ed), Miscast: Negotiating the Presence of the Bushmen. Cape Town: UCT Press.

Penn, N. 2005. The Forgotten Frontier: Colonist and Khoisan on the Cape's Northern Frontier in the 18th Century. Cape Town: Double Storey.

Prins, F. 1990. 'Southern Bushmen descendants - trance and rainmaking in Transkei'. South African Journal of Ethnology 13(3): 110-16.

Prins, F. 1992. 'Bushmen as mediators in Nguni cosmology'. Ethnology 31(2): 133-48.

Prins, F. 1996. 'Praise to our Bushman ancestors of the water: The integration of San related concepts in a diviner's training school', in P. Skotnes (ed), Miscast: Negotiating the Presence of the Bushmen. Cape Town: University of Cape Town Press.

Prins, F. 2009. 'Secret San of the Drakensberg and their rock art'. Critical Arts 23(2): 190-208. Said, E. 1991. Orientalism. Harmonsdworth: Penguin.

Sampson. C. 1993. "Zeer Grote Liefhebbers van Tobak": Nicotine and cannabis dependency of the Seacow River Bushmen'. The Digging Stick 10(1): 2-12.

Smith, B. 2010. 'Envisioning San history: Problems in the reading of history in the rock art of the Maloti-Drakensberg Mountains of South Africa'. African Studies 69(2): 345-59.

Solomon, A. 1997. 'The myth of ritual origins? Ethnography, mythology and interpretation of San rock art'. South African Archaeological Bulletin 52: 3-13.

Solomon, A. 2007. 'Images, words and worlds: The |Xam testimonies and the rock arts of the southern San', in P. Skotnes (ed), Claim to the Country: The Archive of Wilhelm Bleek and Lucy Lloyd. Johannesburg: Jacana. 
Spivak, G. 1999. A Critique of Post-colonial Reason: Toward a History of the Vanishing Present. Cambridge: Harvard University Press.

Stow, G. 1905. The Native Races of South Africa: A History of the Intrusion of the Hottentots and Bantu into the Hunting Grounds of the Bushmen, the Aborigines of the Country. London: Swan.

Sullivan, S. \& Low, C. 2014. 'Shades of the rainbow serpent? A Khoesan animal between myth and landscape in southern Africa - ethnographic contextualisations of rock art representations'. Arts 3: 215-44.

Swartz, K., De Prada-Samper, J.M. \& Winberg, M. 2014. 'The wolf and the man', in P. Skotnes \& J. Deacon (eds), The Courage of //Kabbo: Celebrating the 1ooth Anniversary of the Publication of Specimens of Bushman Folklore. Cape Town: University of Cape Town Press.

Thornton, R.J. 1983. “This dying out race”: W.H.I. Bleek's approach to the languages of southern Africa'. Social Dynamics 9(2): 1-10.

Van Vuuren, H. 1994. 'Forgotten territory: The oral tradition of the |Xam'. Alternation: International Journal for the Study of Southern African Literature and Language 1(2): 57-70.

Vinnicombe, P. 2009. People of the Eland: Rock Paintings of the Drakensberg Bushmen as a Reflection of Their Life and Thought. Second edition. Johannesburg: Wits University Press.

Watson, S. 1991. Return of the Moon: Versions from the |Xam. Cape Town: Carrefour Press.

Wessels, M. 2008. 'New directions in |Xam studies: Some of the implications of Andrew Bank's Bushmen in a Victorian World: The Remarkable Story of the Bleek-Lloyd Collection of Bushman Folklore'. Critical Arts 22(1): 69-82.

Wessels, M. 2012. 'A Bushman voice from the Drakensberg: Zanele Mkhwanazi's story'. Current Writing: Text and Reception in Southern Africa 24(1): 58-71.

Wessels, M. 2014. 'The creation of the eland: A close reading of a Drakensberg San narrative'. Critical Arts 28(3): 555-68.

Whitelaw, G. 2009. “Their village is where they kill game": Nguni interactions with the San', in P. Mitchell \& B. Smith (eds), The Eland's People: New Perspectives in the Rock Art of the Maloti-Drakensberg Bushmen. Johannesburg: Wits University Press.

Wintjes, J. 2011. 'A pictorial genealogy: The rainmaking group from Sehonghong shelter'. Southern African Humanities 23: 17-54.

Wittenberg, H. 2012. 'Wilhelm Bleek and the Khoisan imagination: A study of censorship, genocide and colonial science'. Journal of Southern African Studies 38(3): 667-79.

Wright, J.B. 1971. Bushman Raiders of the Drakensberg, 1840-1870: A Study of their Conflict with Stock-keeping Peoples in Natal. Pietermaritzburg: University of Natal Press.

Wright, J.B. 2007. 'Bushman raiders revisited', in P. Skotnes (ed), Claim to the Country: The Archive of Wihelm Bleek and Lucy Lloyd. Johannesburg: Jacana Press.

Wright, J.B. \& Mazel, A. 2007. Tracks in a Mountain Range: Exploring the History of the Ukhahlamba-Drakensberg. Johannesburg: Wits University Press. 